\title{
SELULITIS DENGAN ULKUS VARIKOSUM
}

\author{
Andravita F. Mitaart \\ Herry E. J. Pandaleke
}

\author{
Bagian/SMF Ilmu Kesehatan Kulit dan Kelamin Fakultas Kedokteran \\ Universitas Sam Ratulangi/RSUP Prof. Dr. R. D. Kandou Manado \\ Email: andravitafenti@gmail.com
}

\begin{abstract}
Cellulitis is an acute bacterial infection of dermis and subcutaneous tissue which manifests as an erythematous lesion with an undefined border accompanied with inflammatory signs. It is mainly found in the elderly; more frequently in females than males; with a history of malaise, fever, and pain as the prodromal signs, and enlargement of local lymph nodes. Cellulitis can occur in any body region, most commonly on the lower limbs, followed by the arms, head, and, neck. It tends to occur in sites with prior lesions such as dermatitis, static ulcers (including varicose ulcers), animal bites, or trauma. A varicose ulcer is an ulcer located on the lower limb caused by a disturbance in the venous blood flow. We reported an 80-year-old woman, presented with cellulitis and varicose ulcers. The diagnosis was based on history, clinical signs, and laboratory findings. The therapy consisted of limb elevation; oral antibiotic clindamycin (300 mg), mefenamic acid (500 mg), and mebhydroline napadisilate (50 mg), each three times daily; and a topical therapy that was comprised of a wound dressing using $\mathrm{NaCl} 0.9 \%$ for 30 minutes three times daily and an application of sodium fusidate cream twice daily. After ten days of therapy, there were clinical improvements with wound healing without any sign of cellulitis.
\end{abstract}

Keywords: cellulitis, varicose ulcer

\begin{abstract}
Abstrak: Selulitis merupakan infeksi bakteri akut pada dermis dan jaringan subkutan yang ditandai lesi kemerahan berbatas tidak jelas dan disertai tanda-tanda radang. Umumnya selulitis ditemukan pada usia lanjut, perempuan lebih sering daripada laki-laki, dengan riwayat lesu, demam, dan rasa nyeri sebagai gejala prodromal, disertai pembesaran kelenjar getah bening setempat. Selulitis dapat terjadi pada bagian tubuh manapun dengan predileksi pada tungkai bawah diikuti lengan, kepala, dan leher. Selain itu, selulitis biasanya timbul pada lokasi dengan lesi yang telah ada sebelummya, yaitu dermatitis, ulkus stasis (termasuk ulkus varikosum), luka tusuk, gigitan binatang, atau trauma. Ulkus varikosum ialah ulkus pada tungkai bawah yang disebabkan gangguan aliran darah venosa. Kami melaporkan kasus seorang perempuan berusia 80 tahun dengan selulitis dan ulkus varikosum. Diagnosis ditegakkan berdasarkan anamnesis, gejala klinis, dan pemeriksaan penunjang. Penatalaksanaannya ialah elevasi tungkai; antibiotik oral klindamisin $300 \mathrm{mg}$, asam mefenamat $500 \mathrm{mg}$, dan mebhidrolin napadisilat $50 \mathrm{mg}$, masing-masing 3 kali sehari; kompres solusio $\mathrm{NaCl}$ 0,9\% selama 30 menit 3 kali sehari, dan natrium fusidat krim dioleskan 2 kali sehari. Setelah 10 hari paska terapi, terdapat perbaikan klinis berupa luka yang mulai mengering tanpa disertai tanda-tanda selulitis.
\end{abstract}

Kata kunci: selulitis, ulkus varikosum 
Selulitis merupakan infeksi bakteri akut pada dermis dan jaringan subkutan yang ditandai lesi kemerahan dengan batas tidak jelas dan disertai tanda-tanda radang. ${ }^{1,2}$ Tempat predileksi tersering ialah pada regio ekstremitas bawah, tetapi dapat mengenai lengan, wajah, dan kulit kepala. ${ }^{1}$

Data yang dikumpulkan dari rumah sakit di Amerika Serikat tahun 2005 menunjukkan bahwa selulitis sering ditemukan pada orang dewasa. Sebuah studi di Minnesota menyebutkan selulitis tersering pada ekstremitas bawah yaitu 199 episode per 100.000 orang per tahun. Jenis kelamin tidak memengaruhi, namun bertambahnya usia dikaitkan dengan insiden yang lebih tinggi. ${ }^{3,4}$ Agen penyebab tersering yaitu Staphylococcus aureus dan Streptococcus group A. Escherichia coli dan enterobakteria anaerob lain biasanya terlibat pada selulitis. ${ }^{1}$

Faktor predisposisi pada selulitis antara lain status gizi, higiene perorangan, iklim, penyakit yang mendasari, usia lanjut, dan penurunan fungsi imunologik (antara lain akibat HIV/AIDS). ${ }^{2,5}$

Ulkus varikosum adalah ulkus pada tungkai bawah yang disebabkan oleh gangguan aliran darah venosa. Umumnya hal ini ditemukan pada orang dewasa dan usia lanjut, lebih sering pada perempuan, dan disertai dermatitis stasis. Dermatitis stasis dapat mengalami infeksi sekunder, misalnya selulitis. $^{6}$

Penatalaksanaan selulitis meliputi istirahat, tungkai bawah dan kaki yang diserang ditinggikan (elevasi), sedikit lebih tinggi daripada letak jantung. Pengobatan sistemik ialah pemberian antibiotik, dan secara topikal diberikan kompres terbuka dengan larutan antiseptik. ${ }^{6}$

\section{LAPORAN KASUS}

Seorang perempuan berusia 80 tahun datang ke Poliklinik Kulit dan Kelamin RSUP Prof. Dr. R. D. Kandou Manado 14 Januari 2013 dengan keluhan bengkak kemerahan pada kedua tungkai bawah sejak 1 hari sebelum masuk rumah sakit yang disertai rasa nyeri dan gatal. Awalnya bercak kemerahan di kedua tungkai bawah yang disertai rasa gatal muncul sekitar 4 tahun yang lalu. Pasien sering berobat ke Poliklinik tersebut, dan keluhan ini bersifat hilang timbul. Sejak kurang lebih 1 bulan yang lalu timbul luka di punggung kaki kiri karena digaruk. Awalnya luka kecil yang lama kelamaan meluas. Pada 10 November 2012, punggung kaki kanan terkena air panas yang meninggalkan luka. Pasien mengobati sendiri luka tersebut dengan betadin, namun tidak ada perbaikan. Riwayat penyakit dahulu yaitu hipertensi sejak tahun 2006; pasien sering minum obat nifedipin namun tidak teratur.

Pada pemeriksaan fisik didapatkan keadaan umum tampak sakit sedang, kesadaran kompos mentis, tekanan darah 140/90 mmHg, nadi 90x/menit, respirasi 24 $\mathrm{x} /$ menit, dan suhu badan $36,7^{\circ} \mathrm{C}$. Pada pemeriksaan regio kruris $1 / 3$ distal dan dorsum pedis dekstra et sinistra tampak lesi eritem dan hiperpigmentasi berbatas tidak tegas, hangat pada perabaan, dan ulkus multipel berukuran 2x1x0,5 cm dan $5 \times 3 \times 0,5 \mathrm{~cm}$, tepi tidak teratur, dengan dasar jaringan granulasi (Gambar 1).

Pada pemeriksaan laboratorik sederhana dengan pewarnaan Gram ditemukan kokus gram positif dan negatif. Pemeriksaan hematologik menunjukkan hasil hemoglobin 10,3 g/dL, GD2JPP 101mg/dL sedangkan pemeriksaan lainnya dalam batas normal.

Penatalaksanaan kasus ini berupa elevasi tungkai, antibiotik oral yaitu klindamisin $300 \mathrm{mg}$ 3x/hari, asam mefenamat 500 mg 3x/hari, mebhidrolin napadisilat (Interhistin ${ }^{\circledR}$ ) 3x/hari, kompres dengan solusio $\mathrm{NaCl}$ 0,9\% 3x30 menit per hari, dan natrium fusidat krim 2x oles per hari. Pada hari ke-10 setelah pemberian terapi, sudah tampak perbaikan klinis berupa luka yang mulai mengering dan tidak ditemukan lagi tanda-tanda selulitis (Gambar 2). 


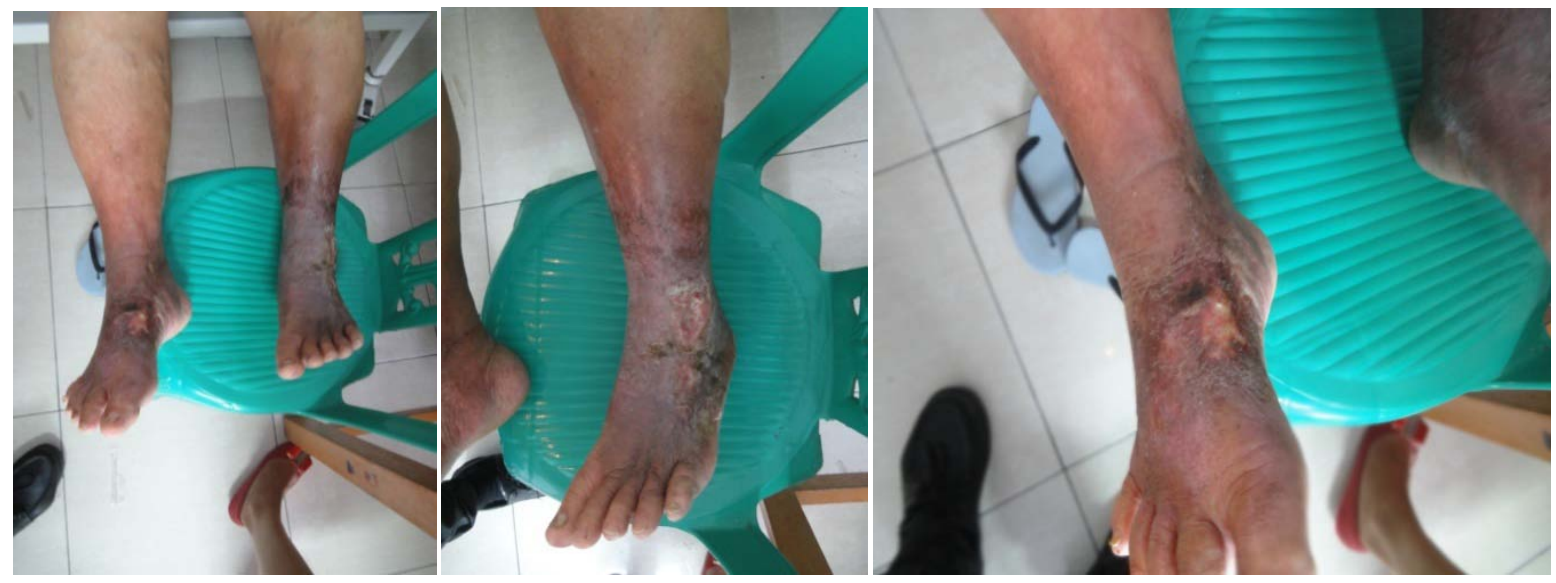

Gambar 1. Tampak lesi eritem dan hiperpigmentasi berbatas tidak tegas pada regio kruris $1 / 3$ distal dan dorsum pedis dekstra et sinistra, hangat pada perabaan, dan ulkus multipel berukuran 2x1x0,5 $\mathrm{cm}$ dan 5x3x0,5 cm tepi tidak teratur, dengan dasar jaringan granulasi (Tanggal 14 Januari 2013 sebelum pemberian terapi).

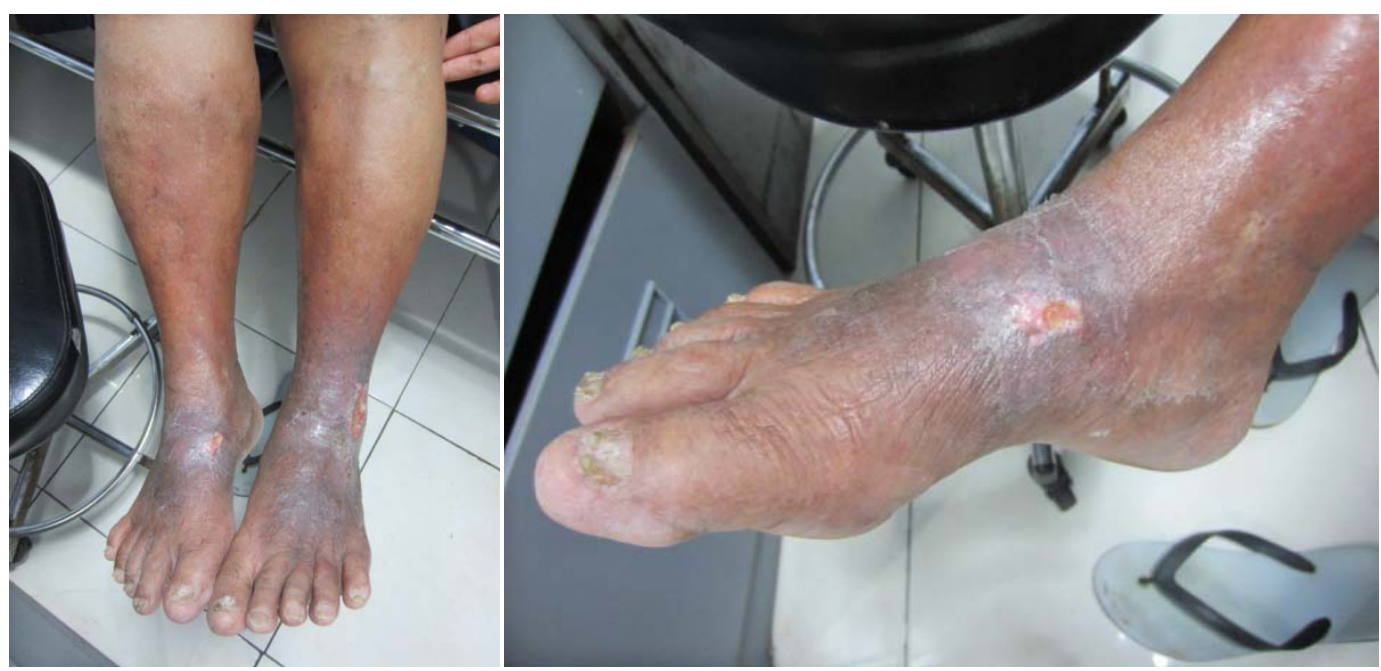

Gambar 2. Tampak luka yang mulai mengering sedangkan tanda-tanda selulitis tidak ditemukan lagi (Tanggal 23 Januari 2013, hari ke-10 setelah pemberian terapi).

\section{BAHASAN}

Diagnosis pada kasus ini ditegakkan berdasarkan anamnesis, pemeriksaan fisik, dan pemeriksaan penunjang. Pada anamnesis ditemukan seorang perempuan berusia 80 tahun dengan keluhan bengkak kemerahan pada kedua tungkai bawah disertai rasa nyeri, yang diawali bercak merah kehitaman disertai rasa gatal serta adanya luka akibat garukan dan akibat terkena air panas. Luka-luka tersebut bernanah, dan kulit sekitarnya bengkak, merah, nyeri, serta hangat pada perabaan. Berdasarkan acuan pustaka, prevalensi selulitis umumnya terdapat pada usia lanjut dengan riwayat lesu, demam, dan rasa nyeri sebagai gejala prodromal serta pembesaran kelenjar getah bening setempat., ${ }^{1,2,5,7}$ Selulitis biasanya didahului oleh adanya trauma, dapat terjadi pada bagian tubuh manapun, tetapi tungkai bawah merupakan tempat yang paling sering terkena infeksi, diikuti lengan, kepala, dan leher. ${ }^{1,5}$ Selain itu, selulitis biasanya timbul pada lokasi dengan lesi yang telah ada sebelummya, yaitu dermatitis, ulkus stasis, luka tusuk, gigitan binatang atau trauma. ${ }^{1}$ Hasil penelususran acuan pustaka di atas seusai dengan yang ditemukan pada kasus ini. 
Pada status dermatologik regio kruris 1/3 distal dan dorsum pedis dekstra et sinistra ditemukan lesi eritem dan hiperpigmentasi, berbatas tidak tegas, hangat pada perabaan, ulkus multipel berukuran $2 \times 1 \times 0,5 \mathrm{~cm}$ dan $5 \times 3 \times 0,5 \mathrm{~cm}$ dengan tepi tidak teratur dan dasar jaringan granulasi. Hal ini sesuai dengan acuan pustaka, dimana pada temuan klinis infeksi jaringan lunak biasanya terjadi akut, difus, tampak merah dan menyebar, terdapat inflamasi supuratif di dermis, subkutan, atau jaringan otot. Kelainan kulit berupa infiltrat yang difus di subkutan disertai tanda-tanda radang akut, yaitu rubor (eritem), kalor (hangat), dolor (nyeri) dan tumor (bengkak). 1,5,7,8

Kasus ini didiagnosis banding dengan erisipelas. Erisipelas ialah penyakit infeksi bakteri akut dengan gejala utama adanya lesi eritem berwarna merah cerah, berbatas tegas, tepi meninggi, dapat disertai edema, vesikel, bula, dan tidak disertai tanda-tanda radang akut. ${ }^{1,2,5,7}$ Pada kasus ini didapatkan lesi eritem yang berbatas tidak tegas dengan tepi tidak meninggi disertai tandatanda radang akut sehingga diagnosis banding erisipelas dapat disingkirkan.

Faktor predisposisi antara lain status gizi, higiene perorangan, iklim dan penyakit yang mendasari, usia lanjut, penurunan fungsi imunologi seperti pada pasien HIV/AIDS. ${ }^{1,2,9}$ Kasus ini telah berusia lanjut dan diduga port d'entree ialah dermatitis stasis pada kedua tungkai bawah. Kelainan ini sudah hilang timbul sejak 4 tahun lalu. Hal ini sesuai dengan acuan pustaka dimana dermatitis stasis dapat mengalami komplikasi berupa ulkus di atas maleolus yang disebut ulkus varikosum atau ulkus venosum; serta dapat pula mengalami infeksi sekunder, misalnya selulitis. $^{10}$

Penatalaksanaan pada kasus ini ialah elevasi tungkai, antibiotik oral klindamisin $300 \mathrm{mg} 3 \mathrm{x} / \mathrm{hari}$ setelah makan, asam mefenamat $500 \mathrm{mg} 3 \mathrm{x} / \mathrm{hari}$ bila nyeri, mebhidrolin napadisilat (Interhistin ${ }^{\circledR}$ ) 3x/hari bila terasa gatal, kompres dengan solusio $\mathrm{NaCl}$ 0,9\% 3x30 menit per hari, dan natrium fusidat krim 2x oles pada luka per hari. Perawatan dari lesi lokal selulitis termasuk tirah baring dan elevasi dari area yang terlibat untuk mengurangi edema setempat. ${ }^{1}$ Solusio $\mathrm{NaCl}$ 0,9\% yang digunakan untuk kompres bersifat normal secara fisiologik, isotonik dengan plasma, dan dapat melembabkan lingkungan sekitar untuk penyembuhan luka. ${ }^{11}$ Antibiotik yang sesuai diberikan dalam dosis lengkap secara intramuskular atau intravena pada kasus yang lebih berat sehubungan dengan adanya sepsis, artritis, atau suspek fasitis, sedangkan pengobatan oral dapat diberikan pada kasus yang lebih ringan dengan infeksi tanpa komplikasi. Pada kasus selulitis, umumnya pengobatan ditujukan terhadap Streptococcus pyogenes dan Staphylococcus aureus. ${ }^{2,7}$ Pilihan antibiotik lini pertama ialah flukloksasilin dan golongan penisilin. Bila alergi terhadap penisilin, dapat digunakan antibiotik golongan makrolid atau klindamisin sebagai alternatif. Klindamisin dapat menekan produksi toksin dari grup streptokokus, $C$. Prefringens, dan stafilokokus aureus. ${ }^{12}$ Pada kasus ini ditemukan riwayat alergi terhadap obat golongan penisilin. Antihistamin diberikan untuk mengurangi rasa gatal yang dapat memperparah dermatitis stasis. Pada kasus ini diberikan antihistamin golongan H1-sedatif untuk mengatasi rasa gatal. $^{13}$ Bila luka telah kering dapat diberikan krim natrium fusidat sebagai antibiotik topikal yang bekerja menghambat sintesis protein dengan aktivitas spesifik terhadap stafilokokus dan mempunyai daya penetrasi tinggi, sehingga dapat mencapai lapisan lebih dalam. ${ }^{14,15}$

Selulitis bukan merupakan penyakit yang mengancam nyawa namun dapat berkembang menjadi sepsis bila tidak diberikan pengobatan segera. Prognosis quo ad vitam dan quo ad functionam pada kasus ini ialah dubia ad bonam. Quo ad sanationam pasien ini ialah dubia karena tingginya kemungkinan rekurensi mengingat adanya faktor predisposisi yang belum ditangani yaitu dermatitis stasis dan ulkus varikosum. 


\section{SIMPULAN}

Telah dilaporkan satu kasus selulitis dan ulkus varikosum pada seorang perempuan berusia 80 tahun, dengan riwayat trauma dan dermatitis statis yang diduga sebagai faktor predisposisi.

Diagnosis ditegakkan berdasarkan anamnesis, pemeriksaan fisik, dan pemeriksaan penunjang. Pada kasus ini ditemukan adanya ulkus dan pembengkakan kemerahan pada kedua tungkai bawah sejak 1 hari sebelum masuk rumah sakit yang disertai rasa nyeri dan gatal.

Penatalaksanaan berupa elevasi tungkai, antibiotik oral klindamisin $300 \mathrm{mg}$ $3 \mathrm{x} /$ hari, asam mefenamat $500 \mathrm{mg} 3 \mathrm{x} / \mathrm{hari}$, mebhidrolin napadisilat (Interhistin ${ }^{\circledR}$ ) 3x/hari, kompres dengan solusio $\mathrm{NaCl}$ 0,9\% 3x30 menit per hari, dan natrium fusidat krim 2x oles per hari. Setelah 10 hari paska terapi, terdapat perbaikan klinis berupa luka yang mulai mengering sedangkan tanda-tanda selulitis tidak tampak lagi.

\section{DAFTAR PUSTAKA}

1. Saavedra A, Weinberg AN, Swartz MN, Johnson RA. Soft tissue infections: Erysipelas, cellulitis, gangrenous cellulitis, and myonecrosis. In: Wolff K, Goldsmith LA, Katz SI, Gilchrest BA, Paller AS, Leffel DJ, editors. Fitzpatrick's Dermatology in General Medicine (Eight Edition). New York: McGraw Hill; 2012; p. 1720- 31.

2. Hay RJ, Adriaans BM. Bacterial infections. In: Burn $\mathrm{T}$, Breathnach $\mathrm{S}$, Cox $\mathrm{N}$, Griffiths C, editors. Rook's Textbook of Dermatology (Eight Edition). Singapore: Willey-Blackwell Publishing; 2010; p. 30.1-30.82.

3. Rogers RL, Perkins J. Skin and soft tissue infections. Prim Care Clin Office Pract. 2006; 33:697-710.

4. McNamara DR, Tleyjeh IM, Berbari EF, Lahr BD, Martinez JW, Mirzoyev SA. Incidence of lower-extremity cellulitis: a population-based study in Olmsted county, Minnesota. Mayo Clin
Proc. 2007;82(7): 817-21.

5. James WD, Berger TG, Elston DM. Bacterial infections. In: James WD, Berger TG, Elston DM. Andrew's Disease of the Skin (Tenth Edition). Philadelphia: Saunders Elsevier; 2006. p. 251-95.

6. Sularsito SA. Ulkus kruris. In: Djuanda A, Hamzah M, Aisah S, penyunting. Ilmu Penyakit Kulit dan Kelamin (Edisi ke 6). Jakarta: Badan Penerbit FKUI; 2010. p. 245-52.

7. Blume JE, Levine EG, Heymann WR. Bacterial infectionss. In: Bolognia JL, Jorizzo JL, Schaffer JU, editors. Dermatology (Third Edition). Edinburgh; Elsevier; 2012; p. 1124-4.

8. Wingfield C. Diagnosing and managing lower limb cellulitis. Nursing times. 2012; 108(27): 18-21.

9. Sjarial. Infeksi bakteri stafilokok dan streptokok. In: Harahap M, penyunting. Ilmu Penyakit Kulit, Jakarta: Hipokrates: 1998. p. 53-5.

10. Sularsito SA, Djuanda S. Dermatitis. In: Djuanda A, Hamzah M, Aisah S, penyunting. Ilmu Penyakit Kulit dan Kelamin (Edisi ke 6). Jakarta: Badan Penerbit FKUI; 2010. p. 129-53.

11. Shai A, Maibach HI. Wound healing and ulcers of the skin: Diagnosing and therapy-The Practical Approach. Heidelberg: Springer-Verlag Berlin Heidelberg; 2005.

12. The Clinical Resource efficiency Support Team (CREST). Guidelines on the management of cellulitis in adults. Belfast-North Ireland; 2005.

13. Limb SL, Wood RA. Antihistamines. In: Wolff K, Goldsmith LA, Katz SI, Gilchrest BA, Paller AS, Leffel DJ, editors. Fitzpatrick's Dermatology in General Medicine (Eight Edition). New York: McGraw Hill; 2012; p. 2776-87.

14. Jazid IZ. Pemakaian antibiotik topikal pada penyakit kulit. MDVI. 2002;29(1):320-6.

15. Wes DP, Micali G. Principles of pediatric dermatological therapy. In: Harper J, Oranje A, Rose N, editors. Textbook of Pediatric Dermatology. Massachusetts: Blackwell Science Ltd; 2000; p. 1738-40. 